\title{
Ethnological Conference in Bremen
}

FROM 14 to 17 June 1954 an ethnological conference was held in Bremen. Among other papers concerned with Spain, Sumatra, Bolivia, and North America, the following studies in African ethnology were presented: Dr. Haberland of Frankfurt, "Field research among the Borana-Galla '; Dr. Herzog of Göttingen, a report of a recent expedition to Kordofan and Nubia; Dr. Prins of Groningen, 'Shungwaya, the original home of the North-eastern Bantu'; Frl. Dr. Schlosser of Kiel, 'The cultural situation of natives in South Africa today '; Frl. Dr. Sulzmann of Mainz, 'Iyaya and Bobongo-The dances of the Ekonda'. At the conclusion of the conference it was agreed that the next conference of the German Ethnological Association should be held in Berlin.

\section{South African Institute of Race Relations}

THE Southern Transvaal Regional Committee has established a central study group which meets twice a month, starting from February 1955, to discuss a wide range of topics on the general theme of 'Peoples and Policies in South Africa'. The subjects planned include: the historical background; general population distribution; urban and rural distribution; urbanization and industrialization; concept of western civilization.

\section{An African Drama (Côte d'Ivoire)}

A THEatrical performance was presented in June I954 by two drama groups of the Cercle Culturel et Folklorique of the Côte d'Ivoire. The main feature of the entertainment was a play by F. Amon d'Aby, Kwao Adjoba; the play portrayed the efforts of a man and his wife to create a cocoa-plantation, and their success after long struggles against many difficulties. But this success, and the man's affluence and liberality to his own children, arouse the anger and jealousy of his maternal kin who, in a matrilineal society, are his heirs and resent his dissipation of the fortune which should be theirs. In the end, the heirs encompass his death and dispossess his wife and children. The play, though open to criticism on several scores, made a profoundly moving impression on a large audience and was described as ' le drame de la succession matriarcale, court, brutal'.

\section{The Somaliland Society}

THE Somaliland Society was formed in September 1954 at a meeting of interested persons in Hargeisa. Its objects are to promote an interest in, and knowledge of, the history, languages, legends, customs, economics, arts, and natural sciences of Somaliland. A council and editors have been elected; membership is open to all on payment of a minimum subscription of $s s$. per annum. It is proposed to publish a half-yearly Journal which will be written mainly in English, though some Arabic material may be included. From time to time lectures, discussions, and other activities will be arranged. The Hon. Secretary is Mr. J. M. Watson and the Hon. Treasurer Mr. Mohamoud Abdi Arraleh.

\section{Survey of Current Research on the Middle East}

THE Middle East Institute, a private organization in Washington, D.C., is preparing for publication an annual Survey of Current Research on the Middle East. The purpose of this Survey is to provide scholars and educational institutions with information on what research has recently been completed or is now being undertaken in the field.

Definition of research: (I) accumulation of original data; (2) classification of original data; 